\begin{tabular}{c|c|c|c|c|c|c|c}
\hline $\begin{array}{c}\text { Geld- } \\
\text { nemer }\end{array}$ & Bedrag & $\begin{array}{c}\text { Datum } \\
\text { sluiting }\end{array}$ & $\begin{array}{c}\text { Januari } \\
\text { 0\% Bedrag }\end{array}$ & $\begin{array}{c}\text { Februari } \\
\text { \%o Bedrag }\end{array}$ & $\begin{array}{c}\text { Maart } \\
\text { 0\% Budı }\end{array}$ & enz. & $\begin{array}{c}\text { Datum } \\
\text { Aflossing }\end{array}$ \\
\hline
\end{tabular}

Voor hurn, pachten, hypotheekrenten, assurantiepremies enz. liumnen gelijksoortige overzichten worden vervaardigd.

Wanneer of een eenvoudige wijze geconstateerd kan worden. dat de boeking steeds op den juisten datum heeft plaats geronden en de controle dus nog slechts heeft vast to stellen, of het jaartotaal goed verantwoord is, dan kan, met behulp der acten, polissen enz. cen nog beknopter overzicht worken samengresteld, en wel:

\begin{tabular}{|c|c|c|c|c|c|}
\hline \multirow{2}{*}{ Datum } & \multirow{2}{*}{ Omschrijving } & \multicolumn{2}{|c|}{ Loopende jaar } & \multicolumn{2}{|c|}{ Komende jaar } \\
\hline & & bij & af & bij & af \\
\hline Jan. 1 & $\begin{array}{l}\text { Totaal aan het begin } \\
\text { van het jaar .... } \\
\text { Achterstand vorig jaar } \\
\text { Mutaties }\end{array}$ & $f$ & & $f \ldots \ldots \ldots \ldots$ & \\
\hline
\end{tabular}

Men stelt vast, welk bedrag als ontrangen verantwoord moet worden, volgens den toestand aan het begin van het gecontrolcerde boekjaar, en met behulp der documenten de mutaties, welke zich in dat jaar hebben voorgedaan. Deze mutaties worden in het overzicht opgenomen, en wel die, welke invloek hebben op de in het loopende jaal te ontvangen bedragen, in een der eerste twee geldkolommen en die, welke het jaartotaal blijvend wijzigen, in cen der twee volgende kolommen. Ifierdoor stelt men vast, welk total bodrag in het gecontroleercle jaar ontvangen moet zijnn, en ten dienste van de volgende contrôle het bedrag, volgens den toestand, bestaande aan het begin van het nieuwe boekjaar.

b. Debiteuren en Crediteuren. Wanneer de opdracht van den accountant slechts inhoudt do juistheid van de jaarrekening vast te stellen en hij niet alansprakclijk is voor de eredictverleening aan afnemers en tijdige inning der rorderingen, kan hij zijn controle beperken tot het raststellen van het totaal aan debiteuren en crediteuren en de samenstelling van dexe beide saldi. Het totaal wordt tijdens de contröle vastgesteld. De samenstelling kan blijken door de dehitcuren- en crediteurenadministratiën volledig te controleeren. Doch als de of dracht niet verder gaat, dan boven vermeld, dient getracht te worden op eenvoudiger wijze do detailleering van het gecontrolecrde totaal vast te stellen. Bijv. door het verkrijgen van saldoverklaringen; het nagaan van de wijze van voldoening der saldi in het nieuwe bockjaar (op zichzelf reeds noodig voor het beoordeelen der solvabiliteit der debiteuren en on te constateeren of crediteurensaldi wellicht ongeboekt bleven), soms mot behulp ran een in gebruik zijnde hijzondere wijze van disponeeren of op welke andere wijze dan ook, zal men moeten trachten aan de omslachtige detail-contrôle en het daaraan verbonden doubleeren van eijfers te ontkomen.

c. Goederenvoorraad. Ook bij de goederenbeweging dient getracht te worden de contrôle van de geheele voorraadadministrutic te ontgaan, (loor op ecnvoudiger wijze te trachten de juistheid vast te stellen van de keten: heginvoorraad (1) + aankoopen (2) - verkoopen (3) = eindvooraad (4). De factoren 1 en 4 zijn, bijv. doordat men aanwezig is bij de inventarisatie, door opgaven van veem of bank of op andere wijze, vast te stellen. Wr moet dus naar gestreefd worden tijdens de controle voldoende gegevens te kumnel vastleggen, warruit de factoren 2 en 3 kumnen worden vastgesteld. Bijr. door tabellarische inen verkoopboeken, wanneer het aantal artikelen niet groot is. Wanncer de waarden der goederensoorten onderling weinig versehillen, is dikwijls het gewicht of het aantal voldoende zeker; roolal bij artikelen ran een bepaald fabrieksmerk, omdat daarbij de kans, dat verkochte duurdere artikelen vervangen worden door ingekochte goedkoopere, zeer gering is. Bij artikelen met gloote verscheidenheid is dikwijls nog con collectieve contrôle toc te passen, wanneer vaste winstopslagen gebruikelijk zijn. Bịj warenhuizen wordt de voorraad-contrôle op de goederen, welke het magazijn verlaten hebben, eenvoudig nitgeocfend met hehulp van de verkoopwarde. De stands worden n.l. bij ontvangst van goederen voor de verkoopwaarde gedebitcerd, bij verkoop gecrediteerd. Het saldo moet dan steeds de rerkoopwarde van den voorraad aangeven.

d. Invichting der administratie. Bij de inrichting der administratie moet, behalve op de versehillende cischen, tevens gelet worden op die van een efficiünte accountantscontröle. Zelfs ecn wijziging in een bestaande, goed functionecrende hockhouding, kan hierdoor gemotiveerd zijn. De bestaande tocstand kan de contrôle, wanncer deze achteraf geschiedt, in een bepaalde richting dwingen. Zoo kan het feit, dat de kas- en bankbescheiden naar rekeninggroepen gesorteerd zijn, het in hepaalde gevallen wenschelijk maken te controleeren per grootboekrekening, z.g. lijncontrôle toe te passen, in plaats van de reel doeltreffender controle, welke uitgaat van de hulpbocken, doeh die in het bedoelde geval al te veel tijd in beslag zou nemen.

e. Interne controte. Of de accountant bij de door hem uitgeoefende controle mag gebruik maken van de bestaande interne contrôle is nog steeds een strijhlviag. Hoe men ook over dezo kwestie moge denken, het is een feit, dat de accountant bij cen onderneming met cen goed functioneerende interne contrôle herhaleir moct, wat leeds op twee verschillende wijzen, onafhankelijk van elkaar, door het personeel gedaan werd. Een oplossing ter roorkoming van dezen dubbelen arbeid zou gevonden kumen worden door het contrôle-personeel der gecontroleerde zaak te vervangen dool assistenten van den accountant. In dat geval wordt geen dubbel werk verricht en kan de accountant op de resultaten van deze, door zijn eigen personeel nitgeoefende controle steunen. Het is mij niet bekend, of dit systeem reeds toepassing vindt, doch overwogen kan het zcker worden.

M. C. WINTERSTEYN

\section{EEN PAAR BEDENKINGEN}

Naar annlciding van de vraga, dic Prof. Coudriaan in zijn refelaat op den 18 en Accountantsdag van het N. I. v. A. opwerpt, of trust- en kartelvorming remmend werken op den technischen voornitgang, spreekt hij de stelling nit, dat. ,op dit gebied, zooals op zoovele andere, de beofenaren der bedrijfsleer niet moetcn blijven staan bij datgene, wat de sociale economen bereiken. maar dat juist ongekeerd vanuit de beclrijfsleer de grondslagen moeten worden gelegd voor een veel scherper, veel vollediger, veel fijucr vertakte sociale economie".

Dit wordt nader toegclicht door de opmerking, dat de gestclde vraag ,geen vraag (is) waarvan men zich met algemecnlieden moet trachten af te maken, maar een psychologische vraag (is). waarop het antwoord afhangt van het karakter van de ondernemers en de hedrijfsleiders in den betrokken hedipijfstak". terwijl daaragn aansluitend wordt gezegd:

.Het (dit vraagstuk, deze vraag) is een onderdeel van het ontraglijk hociende, maar nog niet geschreven hoofdstuk uit de bedrijfsleer, dat zal handelen over de psychologie van den ondernemer. over zijn temperament en over de hem roortstuwende motieven". 
Veldelop heet het dan nog eens:

.Een viuchthare behandeling van het onderwerp (de opgeworpen vlaag) zou cen analyse moeten geven van de ondernemerstypen in takken van groot- en kleinbedrijf in de verschillende landen en van de wijzigingen, die daarin zijn opgetreden in den loop der jaren. Ook van den invloed, dien de toenenende scheiding tusschen kapitaalbezit en bedrijfsleiding op de ondernemersfiguur heeft gehad. En deze analyse zon zich weer niet mogen bepalen tot vage algemeenheden maar de exactheid mocten bezitten van de moderne empirische psychologic, zooals deze door G. II eijmans, William Stern e.a. is ontwikkcld'.

In deze aanhalingen hebben mij in het bijzonder de volgende punten getroffen, waarover ik mij zou willen veroorloven enkcle opmerkingen te maken.

1. Gezegd wordt, dat vanuit de bedrijfssleer de grondslagen moeten worden gelegd voor cen betere sociale econonie (dan spreker, zoo zal ik moeten aanvullen, tot mu toe bekend is).

2. Wat in het bijzondes de opgeworpen vraag betreft, zij lieet een onderdeel van het hoofdstuk der bedrijfslecr, dat zal handelen over de psychologie van den ondernemer. De termen, die Prof. Croudriaan gebruikt geven mij aanleiding on te vermoeden, dat hij daarbij veel meer denkt an de individuecle dan de sociologische psychologie.

Ad 1. Vooraf moge ik opmerken het te betreuren, dat Prof. Coudriaan over Pedrijfsleer spreekt, als hịj Bedrijfshuishoud kunde bedoelt. (If bedoelt hij iets anders? Fr bestaat voor mij geen reden dit aan te nemen, daar het mij bekend is, dat de Rotterdamsche vakgelecrden bij voorkeur het eerste, de Amsterdamsche het tweede woord gebruiken, als zij het blijkbaar over hetzelfde hebben. Mij zij het vergunt het goed Hollandsche de roorkeur boven het vertaalde te geven en den wensch uit te :preken, dat de hierbij betrokken Nederlandsche geleerden door de schrapping van het woord bedrijfsleer uit de terminologie der Huishoudkunde een begin zullen maken met een overeenkomst omtrent de schepping eener ondubbelzinnige vakterminologie. $\mathrm{F}^{\mathrm{l}}$ is op dit terrein $\mathrm{nog}$ veel te normaliseeren. Men beginne slechts; den tijd heeft men mee. Ik wilde echter vragen, hoc de opmerking van Prof. Goudriaan te begrijpen is.

Met „Sociale ccomomie" wordt, weet ik wel, dat deel der Fconomische Wetenschap bedoeld, dat in het Hollandsch Volkshishoudkunde ook wel Staathuishoudkunde wordt genoemd, de kunde of leer der toepassing van het economisch beginsel op de volkshuishouding, inbegrepen de leer der financiën, terwijl de bedrijfshuishoudkunde de kmmde of leer der toepassing van dit beginsel door de het volk uitmakende personen of persoonscomplexen in hunne bedrijven kan worden genocmd. Prof. Goudriaan zal het met mịj eens zijn, dat deze beide deelen, deelen ran hetzelfde zịn, d.w.z. van één wetenschap der Economie; doch als dit zoo is, dan vraag ik mij af, hoe „vanuit" het eene deel de grondslagen van het andere kunen worden gelegd. Hoe heb ik mij dat te denken? Het gaat in de wetenschap der economie om de uitwerking van het economische beginsel. Dit is zoowel in de volks- als in de bedrijfshuishouding het geval en steeds zijn de menschen in hun samenleving, of de menschelijke samenleving daarbij de gegeven grootheden of grootheid.

Hoe kan het dan zijn, dat het een grondslag, dat wil in de wetenschap zeggen, vooronderstelling van het andere zou zịjn?

De vooronderstellingen eener wetenschap behooren, dat is 7.00 per definitie, niet tot haar gebied, kumnen dus ook geen deel van haar uitmaken, doch zijn aan het gebied van een andere wetenschap, of van andere wetenschappen ontleend.

Ad. 2. Daar gelaten, dat niet is in te zien, warom de in don aanvang vermelde vraag niet evenzeer een vraagstuk der psyche van de ommiddellijk of middellijk onder den ondernemer of leider werkende menschen zou zijn, vraag ik mij tevergeefs af, hoe Prof. Goudriaan er toe komt, het „hoofdstuk over de psychologie van den ondernemer" een , nog niet geschreven" hoofdstuk der bedrijfsleer te noemen.

Economie is toch geen psychologie, evenmin als deze sociologie is.

Sedert Franz Oppenheimer, wij mogen wel zeggen ,ontdekt" heeft, dat de economie haar ontstaan niet aan een finale, doch cen modale drijfveer dankt, weten we, dat de economie een systeem van middelen is, Zijj behoort tot de sociologische wetenschappen, als leer van de uitwerking van den economischen imperatief in de als socii levende menschen.

De economie heeft als ,gegeven " van de algeneene sociologie deze door haar bepaalde samenleving of samenlevenden aan te nemen, doch zij determineert haar en hen zelve niet. Aan de Sociologie ligt ten grondslag, dus buiten haar, de individueeleen de sociologische psychologie van mensch en maatschappij; wat de psychologische wetenschap leert is der sociologie op haar beurt ,gegeven". De psychologie is dus grondslag of vooronderstelling van een grondslag of vooronderstelling der economie.

De sociologie bepaalt - de psychologie in har beide deelen gehoord - hoe de ondernemer, om nu mét Prof. Goudriaan bij dezen te blijven - door de omstandigheden der samenleving, waarvan hị deel uitmaakt, gedetermineerd is en de bedrijfshuishoudkunde zegt op welke wijze dit aldus door zede, recht, klasse enz. bepaalde type zich zal of moet gedragen, als het met kostende dingen naar het economisch beginsel handelt. reyeven, zegt dit onderdeel van een onderdeel der economie. deze en die onstandigheden van technischen en finantieelen aurd, gegeven, deze monopolie- en marktverhoudingen, gegeven, deze verwachtingen, dan zal de ondernemer zus of zoo doen, als en voorzoover hij het economisch beginsel volgt.

Het komt mij op deze gronden niet juist voor, dat Prof. Goudriaan over de psychologie als over een deel der beidrïfshuishoudkunde spreekt.

Het spreekt wel van zelf, dat het niet in mij opkomt te willen beweren, dat de groote bedrijvigheid, die de bedrijfshuishoudkunde in de laatste jaren ontwikkelt, de vele en grondige vakarbeid, die op dit terrein geschiedt, niet van belang en heteekenis voor de volkshuishoudkunde zou zijn.

Even natuurlijk is het, dat ik niet bedoel te zeggen, dat de bedrijfshuishoudkundige niets met de psychologie te maken heeft, dat hij haar niet bestudeeren moet. Als vakgeleerde zal hij, uitgaande van zijn speciaal gebied, niet kunnen en mogen nalaten van de vooronderstellingen en grondslagen van zijn studievak kennis te nemen en zich ook eenig inzicht moeten verwerven in de algemeene beginsclen der wetenschappen, die op haar beurt gene beheerschen.

Ik wensch slechts op te komen tegen uitspraken, die de rerwarring op het toch reels zoo zeer door spraak- en begripsverwarring geteisterde gchied der economie slechts kunnen vergrooten.

C. VERWEY

\section{EFFICIËNTIE Red. I. POLAK}

\section{DE ELLIS QUADRUPLEX.}

De fabrikanten van de Ellis-machine streven regelmatig naar vervolmaking van hun product. De eerste modellen, die hier in den handel gebracht werden, hadden, naast een volledige schrijfmachine, een telmachine met twee telwerken, waarin alleen opgeteld, niet afgetrokken kan worden, tenzij met behulp 